\title{
Strength Behavior of Mud Brick in Building Construction
}

\author{
Farraj Al-Ajmi*, Hany Abdalla, Magdi Abdelghaffar, Jamal Almatawah \\ Civil Engineering Department, College of Technological Studies, The Public Authority for \\ Applied Education \& Training, Kuwait \\ Email: *Farraj2010@gmail.com, Jamaln1@hotmail.com
}

Received 20 May 2016; accepted 13 June 2016; published 16 June 2016;

Copyright $@ 2016$ by authors and Scientific Research Publishing Inc.

This work is licensed under the Creative Commons Attribution International License (CC BY). http://creativecommons.org/licenses/by/4.0/

(c) (i) Open Access

\section{Abstract}

The use of earth construction is well established in energy efficient housing. Mud bricks consist of clay, water, and binding material such as rice husks or straw. The advantages of mud brick include its low-cost and great thermal behavior. Although mud brick is considered one of the oldest construction materials, engineers and builders do not have enough information about its mechanical properties. Also there is no accurate design code to follow before construction. This study is devoted to enhance the low compressive strength of mud brick without sacrificing its low thermal conductivity properties. The experimental program in this research includes the use of different admixtures to increase the compressive strength of the basic mud mix. The experimental results show that the increase of cement ratio, as ingredient to a certain limits, can lead to an optimum compressive strength of the brick.

\section{Keywords}

Brick, Cement, Compressive Strength, Mixture, Mud

\section{Introduction}

Earth as mud bricks, has been used in building construction for thousands of years and approximately $30 \%$ of the world's present population still live in earthen shelters [1]. Mud brick is an inexpensive, environmentallyfriendly and abundantly-available building material. It has been used extensively for building construction around the world, particularly in extreme hot, dry desert climates like that of most Arabian countries [2]. In these countries, mud bricks are made by blending mud and water together into a goopy mixture. Traditionally straw is added to improve tensile strength, and may prevent mud bricks from cracking. The mud brick is then

*Corresponding author. 
shaped in a mold of almost any size or shape, or by hand. The brick mixtures are then laid to dry in the heat of the sun for about 25 days before use [3]-[6]. Figure 1 shows new unlaid mud bricks in the Jordan River, while Figure 2 shows buildings made from mud bricks in an old town in Niger.

Mud bricks have several advantages over other conventional building materials, e.g., concrete masonry. These advantages include: a very minimal manufacturing process; skilled labor is not necessary; mud is available from natural resources; inexpensive construction materials; and mud structures are able to perform satisfactorily under hot environmental conditions [7]. However, there are many disadvantages in using mud bricks as building materials. These include: mud brick may tend to erode under rain impact; absorption of water causes swelling of mud brick, while evaporation of water from the mud brick gives rise to shrinkage and cracking; and mud brick is a relatively fragile material, which cannot resist earthquake hazards.

It is known that mud brick technology has been widely used in desert countries due to the widespread existence of silt and clay deposits in these areas. The importance of using mud brick as a building material, however, has not been seriously investigated through scientific experimentation. Therefore, this study aims to investigate: improvements in mud brick consolidation by increasing its durability; and imparting water penetration to mud brick. In this research, the effect of different mud brick components on strength and thermal conductivity properties are investigated. The basic mixture consists of mud (clay and sand), straw and water. Many additives are provided to the basic mixture in order to improve brick properties.

The overall aim of this study is to determine, through extensive experimental investigation, the effect of different mud brick ingredients on strength and absorption, and utilize these results in a forthcoming study on thermal-conductivity properties. With this in mind, the specific objectives of the study are to improve mud brick consolidation by using materials such as soluble silicate, ethoyl silicate, silanes or siloxanes, isocyanates and various polymers agents to treat mud brick permeability. In addition, the effect of using metallic fibers to improve mud brick durability is investigated.

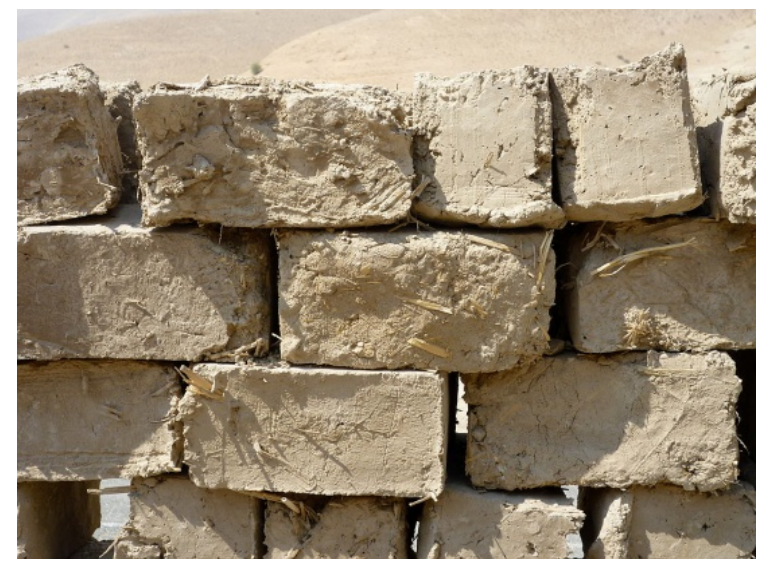

Figure 1. New unlaid mud bricks in the Jordan river.

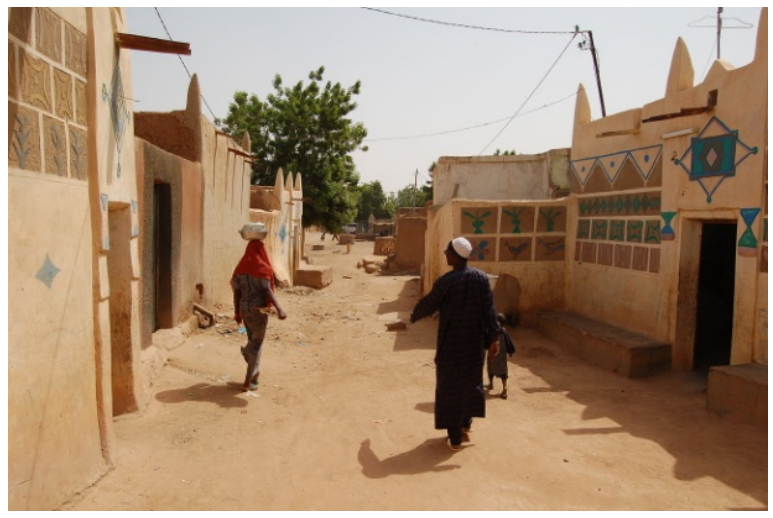

Figure 2. Mud brick building in old town in Niger. 


\section{Materials and Methods}

\subsection{Materials}

The materials used in this study for mud brick production were sand and mud as the main matrix, and hay, cement, lime, Bitumen, steel fibers, and steel filing as fibrous materials.

\subsection{Methods}

In this experimental program, physical tests were carried out on natural mud obtained from Saudi Arabia. The objective of these tests was to analyze and investigate the physical properties of the material used in manufacturing the bricks. A sample of the soil material used in this research is shown in Figure 3. A sieve analysis test was performed on the specimen to determine the grading and the ratio of fines. The soil material was washed on a No. 200 sieve. The results of this test showed a relative ratio of sand to fines as follows: \% Sand $=8.9 \%$ Fines $=91.1 \%$.

Plastic limit and liquid limit tests were carried out on the soil specimen. The plastic limit and liquid limit for the soil specimen were found to be $40.7 \%$ and $81.5 \%$, respectively.

Many factors were considered in the experimental program. These included changing the ingredients of the mixture to reach an optimum compressive strength for the produced brick. The variables considered can be divided into the following ten groups, as shown in Tables 1-10, respectively.

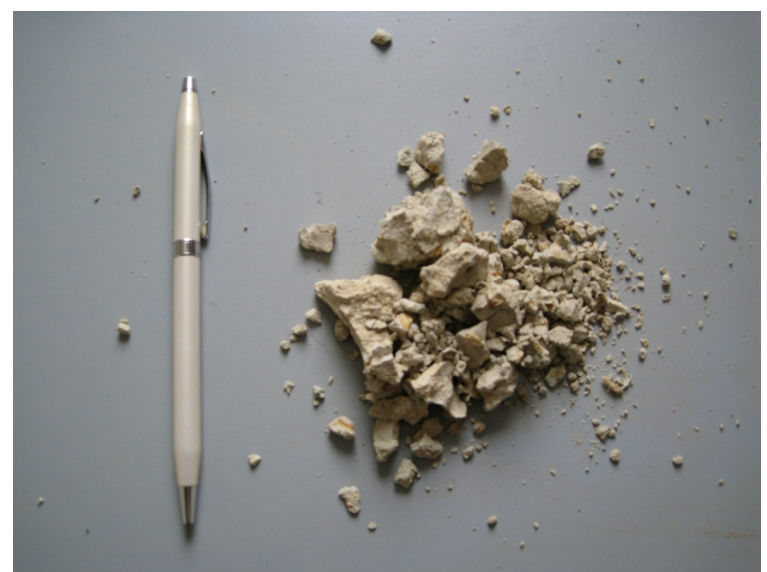

Figure 3. Tested mud.

Table 1. Description of Group 1 (Sand/Mud ratio with constant Hay).

\begin{tabular}{|c|c|c|c|c|c|c|c|}
\hline $\begin{array}{l}\text { Test } \\
\text { No. }\end{array}$ & $\begin{array}{l}\text { Wt. Mud } \\
\text { (gm) }\end{array}$ & $\begin{array}{l}\text { Wt. Sand } \\
\text { (gm) }\end{array}$ & $\begin{array}{l}\text { Sand/Mud } \\
\text { Ratio }\end{array}$ & $\begin{array}{l}\text { Wt. Water } \\
\text { (gm) }\end{array}$ & $\begin{array}{l}\text { Wt. Hay } \\
\text { (gm) }\end{array}$ & $\begin{array}{l}\text { Av. Wt. Sample } \\
\text { (gm) }\end{array}$ & $\begin{array}{l}\text { Av. Load } \\
(\mathrm{kN})\end{array}$ \\
\hline 1 & 4000 & 200 & 0.05 & 2000 & 20 & 1043 & 11.3 \\
\hline 2 & 3820 & 382 & 0.10 & 2000 & 20 & 1079 & 12.1 \\
\hline 3 & 3650 & 548 & 0.15 & 2000 & 20 & 1080 & 15.2 \\
\hline 4 & 3500 & 700 & 0.20 & 2000 & 20 & 1117 & 6.7 \\
\hline 5 & 3250 & 975 & 0.30 & 2000 & 20 & 1159 & 4.8 \\
\hline 6 & 3000 & 1200 & 0.40 & 2000 & 20 & 1165 & 1.6 \\
\hline 7 & 2800 & 1400 & 0.50 & 2000 & 20 & 1150 & 0.0 \\
\hline 8 & 2550 & 1658 & 0.65 & 2000 & 20 & 1143 & 4.2 \\
\hline 9 & 2325 & 1860 & 0.80 & 2000 & 20 & 1131 & 0.0 \\
\hline 10 & 2099 & 2099 & 1.00 & 2000 & 20 & 1142 & 0.0 \\
\hline
\end{tabular}


Table 2. Description of Group 2 (Hay ratio with constant Sand/Mud ratio of 0.15).

\begin{tabular}{cccccccc}
\hline $\begin{array}{l}\text { Test } \\
\text { No. }\end{array}$ & $\begin{array}{c}\text { Wt. Mud } \\
(\mathrm{gm})\end{array}$ & $\begin{array}{c}\text { Wt. Sand } \\
(\mathrm{gm})\end{array}$ & $\begin{array}{c}\text { Wt. Water } \\
(\mathrm{gm})\end{array}$ & $\begin{array}{c}\text { Wt. Hay } \\
(\mathrm{gm})\end{array}$ & $\begin{array}{c}\text { Hay/Soil } \\
(\%)\end{array}$ & $\begin{array}{c}\text { Av. Wt. Sample } \\
(\mathrm{gm})\end{array}$ & $\begin{array}{c}\text { Av. Load } \\
(\mathrm{kN})\end{array}$ \\
\hline 11 & 3650 & 548 & 2000 & 10 & 0.24 & 1112 & 9.0 \\
12 & 3650 & 548 & 2000 & 30 & 0.72 & 1086 & 1.6 \\
13 & 3650 & 548 & 2000 & 50 & 1.20 & 1076 & 2.4 \\
\hline
\end{tabular}

Table 3. Description of Group 3 (Cement ratio with constant Sand/Mud ratio of 0.15-No Hay).

\begin{tabular}{lccccccc}
\hline $\begin{array}{l}\text { Test } \\
\text { No. }\end{array}$ & $\begin{array}{c}\text { Wt. Mud } \\
(\mathrm{gm})\end{array}$ & $\begin{array}{c}\text { Wt. Sand } \\
(\mathrm{gm})\end{array}$ & $\begin{array}{c}\text { Wt. Water } \\
(\mathrm{gm})\end{array}$ & $\begin{array}{c}\text { Wt. Cement } \\
(\mathrm{gm})\end{array}$ & $\begin{array}{c}\text { Cement/Soil } \\
(\%)\end{array}$ & $\begin{array}{c}\text { Av. Wt. Sample } \\
(\mathrm{gm})\end{array}$ & $\begin{array}{c}\text { Av. Load } \\
(\mathrm{kN})\end{array}$ \\
\hline 14 & 3650 & 548 & 2000 & 126 & 3 & 1161 & 12.3 \\
15 & 3650 & 548 & 2000 & 252 & 6 & 1210 & 16.5 \\
16 & 3650 & 548 & 2000 & 378 & 9 & 1196 & 21.0 \\
17 & 3650 & 548 & 2000 & 504 & 12 & 1216 & 21.3 \\
\hline
\end{tabular}

Table 4. Description of Group 4 (Cement ratio with constant Sand/Mud ratio of 0.15 and constant Hay/Soil ratio of $0.48 \%$ ).

\begin{tabular}{cccccccc}
\hline $\begin{array}{c}\text { Test } \\
\text { No. }\end{array}$ & $\begin{array}{c}\text { Wt. Mud } \\
(\mathrm{gm})\end{array}$ & $\begin{array}{c}\text { Wt. Sand } \\
(\mathrm{gm})\end{array}$ & $\begin{array}{c}\text { Wt. Water } \\
(\mathrm{gm})\end{array}$ & $\begin{array}{c}\text { Wt. Cement } \\
(\mathrm{gm})\end{array}$ & $\begin{array}{c}\text { Cement/Soil } \\
(\%)\end{array}$ & $\begin{array}{c}\text { Av. Wt. Sample } \\
(\mathrm{gm})\end{array}$ & $\begin{array}{c}\text { Av. Load } \\
(\mathrm{kN})\end{array}$ \\
\hline 18 & 3650 & 548 & 2000 & 126 & 3 & 1148 & 8.9 \\
19 & 3650 & 548 & 2000 & 252 & 6 & 1184 & 15.7 \\
20 & 3650 & 548 & 2000 & 378 & 9 & 1178 & 5.1 \\
\hline
\end{tabular}

Table 5. Description of Group 5 (Lime ratio with constant Sand/Mud ratio of 0.15-No Hay).

\begin{tabular}{cccccccc}
\hline $\begin{array}{l}\text { Test } \\
\text { No. }\end{array}$ & $\begin{array}{c}\text { Wt. Mud } \\
(\mathrm{gm})\end{array}$ & $\begin{array}{c}\text { Wt. Sand } \\
(\mathrm{gm})\end{array}$ & $\begin{array}{c}\text { Wt. Water } \\
(\mathrm{gm})\end{array}$ & $\begin{array}{c}\text { Wt. Lime } \\
(\mathrm{gm})\end{array}$ & $\begin{array}{c}\text { Lime/Soil } \\
(\%)\end{array}$ & $\begin{array}{c}\text { Av. Wt. Sample } \\
(\mathrm{gm})\end{array}$ & $\begin{array}{c}\text { Av. Load } \\
(\mathrm{kN})\end{array}$ \\
\hline 21 & 3650 & 548 & 2000 & 126 & 3 & 1137 & 0.0 \\
22 & 3650 & 548 & 2000 & 252 & 6 & 1169 & 2.4 \\
23 & 3650 & 548 & 2000 & 378 & 9 & 1165 & 8.3 \\
24 & 3650 & 548 & 2000 & 504 & 12 & 1200 & 9.9 \\
\hline
\end{tabular}

Table 6. Description of Group 6 (Lime ratio with constant Sand/Mud ratio of 0.15 and constant Hay/Soil ratio of $0.48 \%$ ).

\begin{tabular}{cccccccc}
\hline $\begin{array}{l}\text { Test } \\
\text { No. }\end{array}$ & $\begin{array}{c}\text { Wt. Mud } \\
(\mathrm{gm})\end{array}$ & $\begin{array}{c}\text { Wt. Sand } \\
(\mathrm{gm})\end{array}$ & $\begin{array}{c}\text { Wt. Water } \\
(\mathrm{gm})\end{array}$ & $\begin{array}{c}\text { Wt. Lime } \\
(\mathrm{gm})\end{array}$ & $\begin{array}{c}\text { Lime/Soil } \\
(\%)\end{array}$ & $\begin{array}{c}\text { Av. Wt. Sample } \\
(\mathrm{gm})\end{array}$ & $\begin{array}{c}\text { Av. Load } \\
(\mathrm{kN})\end{array}$ \\
\hline 25 & 3650 & 548 & 2000 & 126 & 3 & 1138 & 6.1 \\
26 & 3650 & 548 & 2000 & 252 & 6 & 1162 & 8.0 \\
27 & 3650 & 548 & 2000 & 378 & 9 & 1173 & 3.0 \\
28 & 3650 & 548 & 2000 & 504 & 12 & 1148 & 2.4 \\
\hline
\end{tabular}

Table 7. Description of Group 7 (Lime ratio with constant Sand/Mud ratio of 0.15 and constant Hay/Soil ratio of $0.48 \%$ with Bitumen).

\begin{tabular}{cccccccc}
$\begin{array}{l}\text { Test } \\
\text { No. }\end{array}$ & $\begin{array}{c}\text { Wt. Mud } \\
(\mathrm{gm})\end{array}$ & $\begin{array}{c}\text { Wt. Sand } \\
(\mathrm{gm})\end{array}$ & $\begin{array}{c}\text { Wt. Water } \\
(\mathrm{gm})\end{array}$ & $\begin{array}{c}\text { Wt. Lime } \\
(\mathrm{gm})\end{array}$ & $\begin{array}{c}\text { Lime/Soil } \\
(\%)\end{array}$ & $\begin{array}{c}\text { Av. Wt. Sample } \\
(\mathrm{gm})\end{array}$ & $\begin{array}{c}\text { Av. Load } \\
(\mathrm{kN})\end{array}$ \\
\hline 29 & 3650 & 548 & 2000 & 252 & 6 & 1095 \\
30 & 3650 & 548 & 2000 & 378 & 9 & 1084 \\
\hline
\end{tabular}


Table 8. Description of Group 8 (Lime ratio with no Sand constant Hay/Mud ratio of 0.48\%).

\begin{tabular}{cccccccc}
\hline $\begin{array}{l}\text { Test } \\
\text { No. }\end{array}$ & $\begin{array}{c}\text { Wt. Mud } \\
(\mathrm{gm})\end{array}$ & $\begin{array}{c}\text { Wt. Sand } \\
(\mathrm{gm})\end{array}$ & $\begin{array}{c}\text { Wt. Water } \\
(\mathrm{gm})\end{array}$ & $\begin{array}{c}\text { Wt. Lime } \\
(\mathrm{gm})\end{array}$ & $\begin{array}{c}\text { Lime/Soil } \\
(\%)\end{array}$ & $\begin{array}{c}\text { Av. Wt. Sample } \\
(\mathrm{gm})\end{array}$ & $\begin{array}{c}\text { Av. Load } \\
(\mathrm{kN})\end{array}$ \\
\hline 31 & 4200 & 0 & 2000 & 126 & 3 & 1114 & 7.3 \\
32 & 4200 & 0 & 2000 & 252 & 6 & 1110 & 7.5 \\
33 & 4200 & 0 & 2000 & 378 & 9 & 1136 & 6.2 \\
34 & 4200 & 0 & 2000 & 504 & 12 & 1152 & 11.0 \\
\hline
\end{tabular}

Table 9. Description of Group 9 (Adding Steel Fibers to Mud and Sand with no Hay).

\begin{tabular}{lccccccc}
\hline $\begin{array}{l}\text { Test } \\
\text { No. }\end{array}$ & $\begin{array}{c}\text { Wt. Mud } \\
(\mathrm{gm})\end{array}$ & $\begin{array}{c}\text { Wt. Sand } \\
(\mathrm{gm})\end{array}$ & $\begin{array}{c}\text { Wt. Water } \\
(\mathrm{gm})\end{array}$ & $\begin{array}{c}\text { Wt. Fiber } \\
(\mathrm{gm})\end{array}$ & $\begin{array}{c}\text { Fiber/Soil } \\
(\%)\end{array}$ & $\begin{array}{c}\text { Av. Wt. Sample } \\
(\mathrm{gm})\end{array}$ & $\begin{array}{c}\text { Av. Load } \\
(\mathrm{kN})\end{array}$ \\
\hline 35 & 3650 & 548 & 2000 & 20 & 0.48 & 1105 & 9.1 \\
\hline
\end{tabular}

Table 10. Description of Group 10 (Adding Steel Filing with Lime/Soil ratio of $12 \%$ and Hay/Soil ratio of $0.48 \%$ ).

\begin{tabular}{cccccccc}
\hline $\begin{array}{l}\text { Test } \\
\text { No. }\end{array}$ & $\begin{array}{c}\text { Wt. Mud } \\
(\mathrm{gm})\end{array}$ & $\begin{array}{c}\text { Wt. Sand } \\
(\mathrm{gm})\end{array}$ & $\begin{array}{c}\text { Wt. Water } \\
(\mathrm{gm})\end{array}$ & $\begin{array}{c}\text { Wt. Filing } \\
(\mathrm{gm})\end{array}$ & $\begin{array}{c}\text { Fiber/Soil } \\
(\%)\end{array}$ & $\begin{array}{c}\text { Av. Wt. Sample } \\
(\mathrm{gm})\end{array}$ & $\begin{array}{c}\text { Av. Load } \\
(\mathrm{kN})\end{array}$ \\
\hline 36 & 3650 & 548 & 2000 & 400 & 9.5 & 1175 & 8.2 \\
\hline
\end{tabular}

1. Group 1: Changing the Sand/Mud ratio with constant Hay ratio (Tests No.1 to No.10).

2. Group 2: Changing the Hay ratio with constant Sand/Mud ratio (Tests No.11 to No.13).

3. Group 3: Changing Cement ratio with constant Sand/Mud ratio (Tests No.14 to No.17).

4. Group 4: Changing Cement ratio with constant Sand/Mud ratio and constant Hay ratio (Tests No.18 to No.20).

5. Group 5: Changing Lime ratio with constant Sand/Mud ratio (Tests No.21 to No.24).

6. Group 6: Changing Lime ratio with constant Sand/Mud ratio and constant Hay ratio (Tests No.25 to No.28).

7. Group 7: Changing Lime ratio with constant Sand/Mud ratio and constant Hay ratio with Bitumen (Tests No.29 to No.30).

8. Group 8: Changing Lime with no Sand and constant Mud and Hay ratios (Tests No.31 to No.34).

9. Group 9: Adding Steel Fibers to Mud and Sand with no Hay (Test No.35).

10. Group 10: Adding Steel filing to mud, sand, Lime and Hay (Test No.36).

\section{Mixing of Raw Materials}

The raw materials used in this study were mixed together to reach optimum brick properties. These properties include compressive strength and water absorption without sacrificing the superior advantage of the mud brick, which is heat performance.

\subsection{Sand/Mud Ratio}

The effect of the sand/mud ratio on the behavior of the produced brick was investigated in tests No.1 to No.10 in Group 1. Each test was carried out on three identical specimens. The average value of these specimens is shown in Table 1. The tests were performed to find the effect of the sand/mud ratio on the compression strength of the bricks. The objective of these tests was to reach an optimum ratio to achieve a high compression strength for the bricks.

In this group, tests were done on thirty mud brick specimens with different sand/mud ratios ranging between 0.05 to 1.0. The total weight of the sand and mud was always kept constant and equal to $4200 \mathrm{gm}$ for each batch used to make three bricks with a constant sand/mud ratio. The hay ratio was kept constant in all the specimens for this group. The hay weight was 20 gm representing $0.48 \%$ of the total weight of the mud and sand. Table 1 shows a description for this test group.

The required weights of brick ingredients were prepared for each batch. First, the mud, sand, and hay were mixed in the soil mixer for few minutes, and then water was gradually added. The mud, sand, and hay were 
mixed with natural tap water having no impurities until reaching a homogeneous paste. The mix was then placed and compacted in steel cubic molds having internal dimensions of $100 \times 100 \times 100 \mathrm{~mm}$. After casting the cubic samples, all top surfaces were given a smooth final finish by a straight edge. The brick specimens were taken out of the moulds right after casting and left to dry in the air. Figure 4 shows the brick samples after casting.

\subsection{Hay Ratio}

In specimen Group 2, tests were conducted on nine specimens representing tests No.11 to No.13, Table 2. In these tests, the sand/mud ratio was kept constant at 0.15 while changing the hay weight from $10 \mathrm{gm}$ to $30 \mathrm{gm}$, and $50 \mathrm{gm}$, representing ratios of hay/soil of $0.24 \%, 0.72 \%$, and $1.20 \%$, respectively. It should be noted that a hay ratio of $0.48 \%$ was examined in test No. 3 of Group 1 .

\subsection{Cement Ratio}

Tests No.14 to No.17 of Group 3 were done to examine the effect of adding cement instead of hay as a bonding material to the basic components of the brick (sand and mud). The sand/mud ratio was kept constant at 0.15 in the four tests. The cement ratios considered were 3\%,6\%, $9 \%$, and $12 \%$, and are shown in Table 3 .

\subsection{Cement and Hay Ratio}

In specimens of Group 4, the effect of adding cement together with hay as bonding materials was considered. In tests No.18 to No.20, a sand/mud ratio of 0.15 and a hay ratio of $0.48 \%$ were kept constant in all tests of this group. The cement/soil ratio was varied at $3 \%, 6 \%$, and $9 \%$, as shown in Table 4 .

\subsection{Lime Ratio}

Tests No.21 to No.24 of group 5 examined the effect of adding lime instead of hay as a bonding material to the basic components of the brick (sand and mud). The sand/mud ratio was again kept constant at 0.15 in the four tests. The lime ratios considered were $3 \%, 6 \%, 9 \%$, and $12 \%$, as shown in Table 5 .

\subsection{Lime and Hay Ratio}

In specimens of group 6, the effect of adding lime and hay as bonding materials was considered. In tests No. 25 to No. $28 \mathrm{H}$, a sand/mud ratio of 0.15 and a hay ratio of $0.48 \%$ were kept constant in all tests of this group. The lime/soil ratio was varied at 3\%, 6\%, and 9\%, as shown in Table 6 .

\subsection{Lime, Hay, and Bitumen}

In specimens of Group 7, the effect of adding lime, hay, and bitumen as bonding materials was considered. In tests No.29 and No.30, a sand/mud ratio of 0.15 and a hay ratio of $0.48 \%$ were kept constant in all tests of this

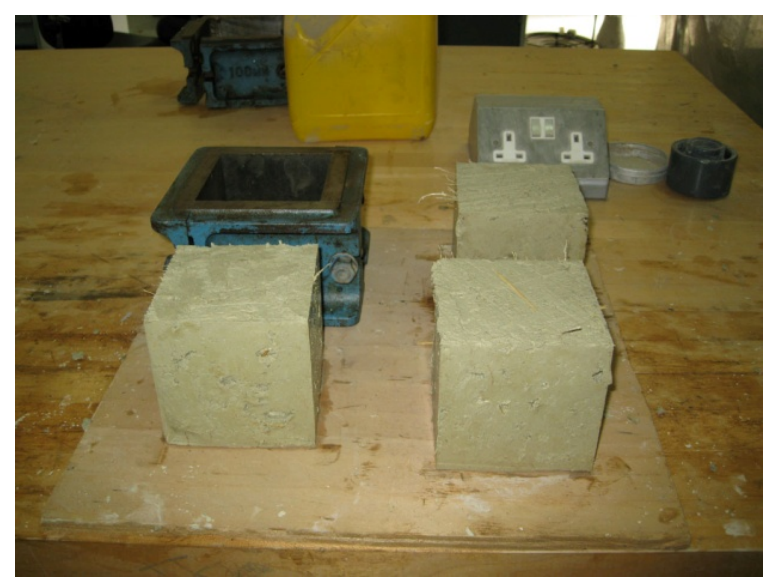

Figure 4. Brick samples after casting. 
group. The lime/soil ratio was varied at $3 \%$ and $6 \%$. Bitumen was added to the specimen until the whole mixture turned black, as shown in Table 7.

\subsection{Lime and Hay (No Sand)}

In specimens of Group 8, the effect of removing the sand from the mixture was considered. The specimens of this group consisted of mud, water, lime, and hay only. The weight of the sand was exchanged for the same weight in mud. This resulted in a ratio of hay to mud of $0.48 \%$ as in the previous groups. The lime ratios in tests No. 31, No. 32, No. 33, and No. 34 were $3 \%, 6 \%, 9 \%$, and 12\%, respectively, as shown in Table 8.

\subsection{Steel Fibers}

Test No.35 of Group 9 examined the effect of adding steel fibers instead of hay as a bonding material to the basic components of the brick (sand and mud). The sand/mud ratio used in this test was 0.15 . The fibers ratio considered was $0.48 \%$, which is the same ratio of hay used in the other tests, as shown in Table 9 .

\subsection{Lime, Hay, and Steel Filings}

Test No.36 of Group 10 examined the effect of adding steel filings to the lime and hay as bonding materials, along with the basic components of the brick (sand and mud). The sand/mud ratio used in this test was 0.15 . The lime ratio was $12 \%$, the hay ratio was $0.48 \%$, while the filings ratio was $9.5 \%$, as shown in Table 10 .

\section{Experiment and Test Procedure}

The testing procedure investigated the strength behavior of the mud brick samples. Experimental measurements were directed to determine the propagation of cracks with an increase of load, the crack pattern before failure, and the ultimate capacity of the brick samples. A California Bearing Ratio (CBR) testing machine was used to determine the compressive strength of the brick samples, Figure 5. Also shown in the figure is the proving ring attached to the vertical jack. This ring, having a capacity of $28 \mathrm{KN}$ was used to monitor the vertically-applied load. All the specimens were loaded until failure.

\section{Test Results}

Tables 1-10 show the failure load for all the specimens. During increases in load, cracks were formed at sides of the tested specimens. Crack width and length increased and eventually lead to final collapse. Figure 6 shows the typical cracking pattern at failure.

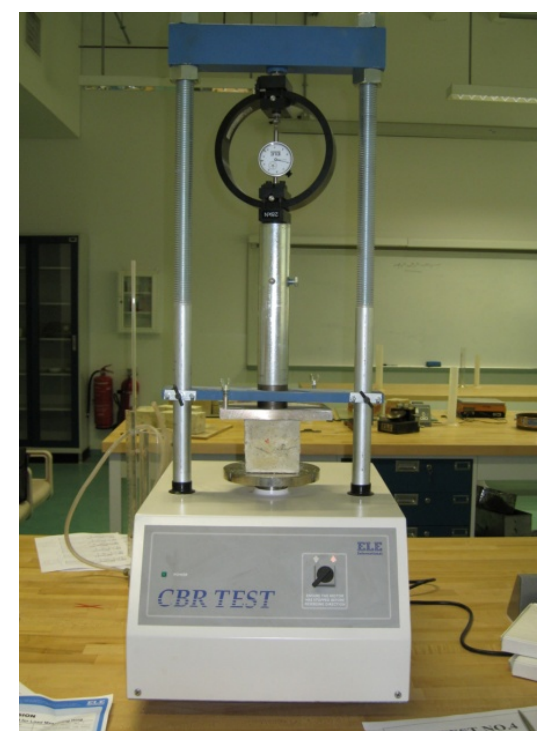

Figure 5. Test setup. 


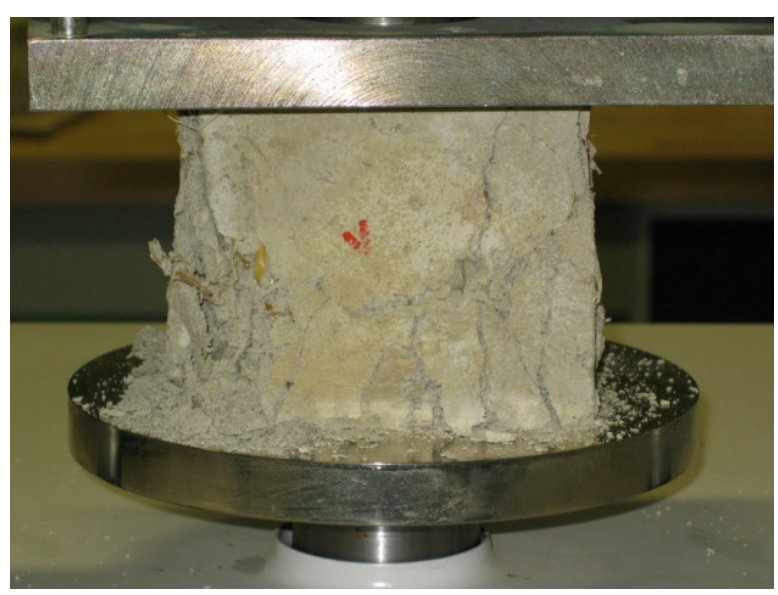

Figure 6. Crack pattern at failure.

Figure 7 shows the effect of increasing the sand/mud ratio on the compressive strength of the produced brick. The results of Group 1 show that average failure load increases with an increase of the sand/mud ratio up to a ratio of 0.15 . Increasing this ratio above 0.15 led to a decrease in the compressive strength of the brick samples. At this optimum ratio, the average failure load of the mud brick samples was $15.2 \mathrm{KN}$ with a compressive strength of 1.52 MPa. As such, this sand/mud ratio was kept constant in the subsequent testing stages. Various materials were added to the basic sample consisting of sand, mud, and water with the sand/mud ratio kept constant 0.15 .

The ratio of hay was the only variable that changed in group 2 of the tests. This group tested hay percentage ratios of $0.24,0.48,0.72$, and 1.2 . Figure 8 shows the effect of increasing the hay ratio in a basic sample. The figure shows that the optimum hay ratio was $0.48 \%$ for the basic sample consisting of sand, mud, and water. This ratio was then kept constant in the following test samples consisting of sand, mud, water, and hay.

In group 3, the hay was exchanged for cement as a bonding material. Figure 9(a) shows that increasing the cement ratio has the effect of increasing the compressive strength.

Comparing Figure 8 and Figure 9(a) shows that the basic sample of sand, mud and water needed cement at 6\% to reach the same compressive strength of the basic sample with only $0.48 \%$ of hay. This indicates that hay is more effective than cement in increasing compressive strength. Moreover, it is well known that increasing the cement in the mixture has a negative effect on the thermal properties of the produced brick [7].

In group 4, tests for cement and hay were added together to the basic sample. The hay ratio was kept at the optimum ratio of $0.48 \%$, while the cement ratio was varied from $3 \%$ to $9 \%$. The results are shown in Figure 9(b). The figure shows that increasing the cement ratio above $6 \%$ decreased load capacity. Moreover, at a cement ratio of $6 \%$ the load capacity was $15.7 \mathrm{KN}$ with an increase of only $3 \%$ in the load capacity when compared to the sample with hay only without cement.

The hay was exchanged by lime as a bonding material in Group 5. The results are shown in Figure 10(a). The results show that increasing the lime ratio increases the load capacity of the brick samples. In Group 5, there was no hay added to the basic mixture.

In Group 6, lime was added to the basic mixture containing sand, mud, and water, in addition to the hay. The hay ratio was kept equal to the optimum ratio of $0.48 \%$ in all specimens of this group. Figure 10 (b) shows the effect of increasing the lime ratio to the basic components of the brick containing hay. The results show that increasing the lime ratio above 6\% had a negative effect on the load capacity of the brick. Comparing Figure 9(b) and Figure 10(b) for specimens with hay in addition to cement or lime, respectively, both figures show a similar trend for compressive strength. This means that in the case of a basic mix with hay, adding an extra bonding material such as cement or lime slightly increases the load capacity up to a limit, after which the strength decreases.

Figure 11 compares the results when adding cement or lime to the basic mixture without hay. The results show that without hay, the cement is more effective than lime in increasing the compressive strength of the produced brick.

The specimens of Group 7 were similar to those of Group 6, except that liquid bitumen was added to the specimens of Group 7. In this case, the brick mix consisted of sand, mud, water, hay, lime, and bitumen. The results 


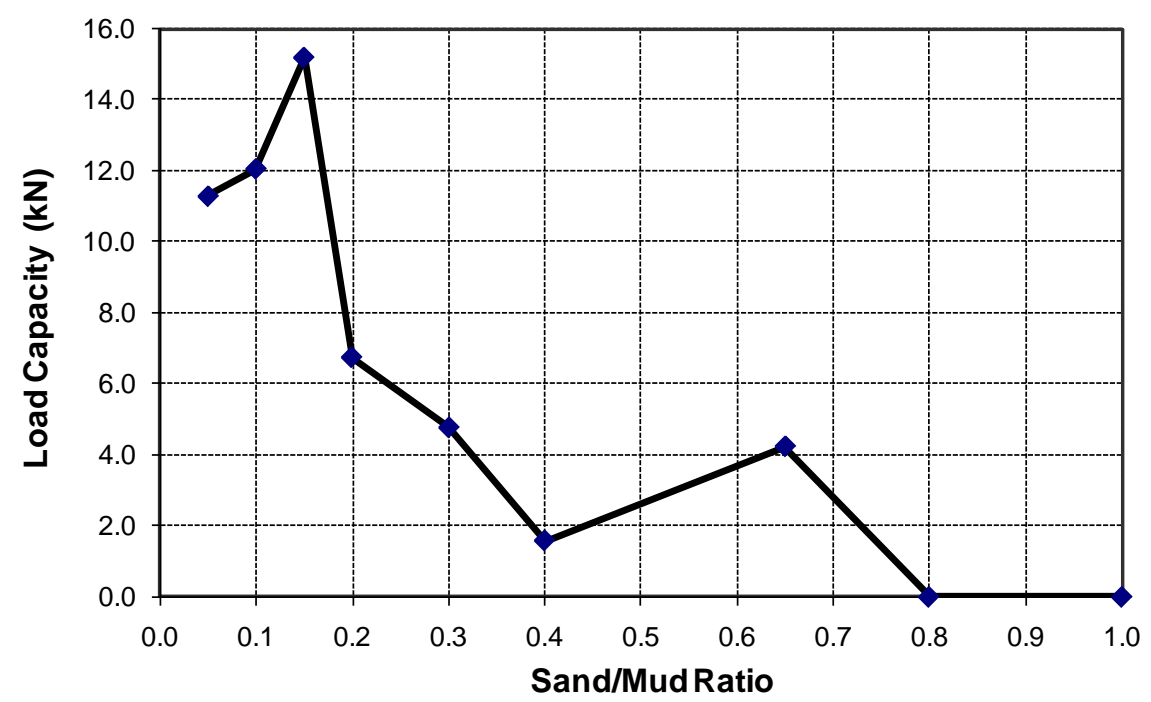

Figure 7. Effect of sand/mud ratio on compressive strength.

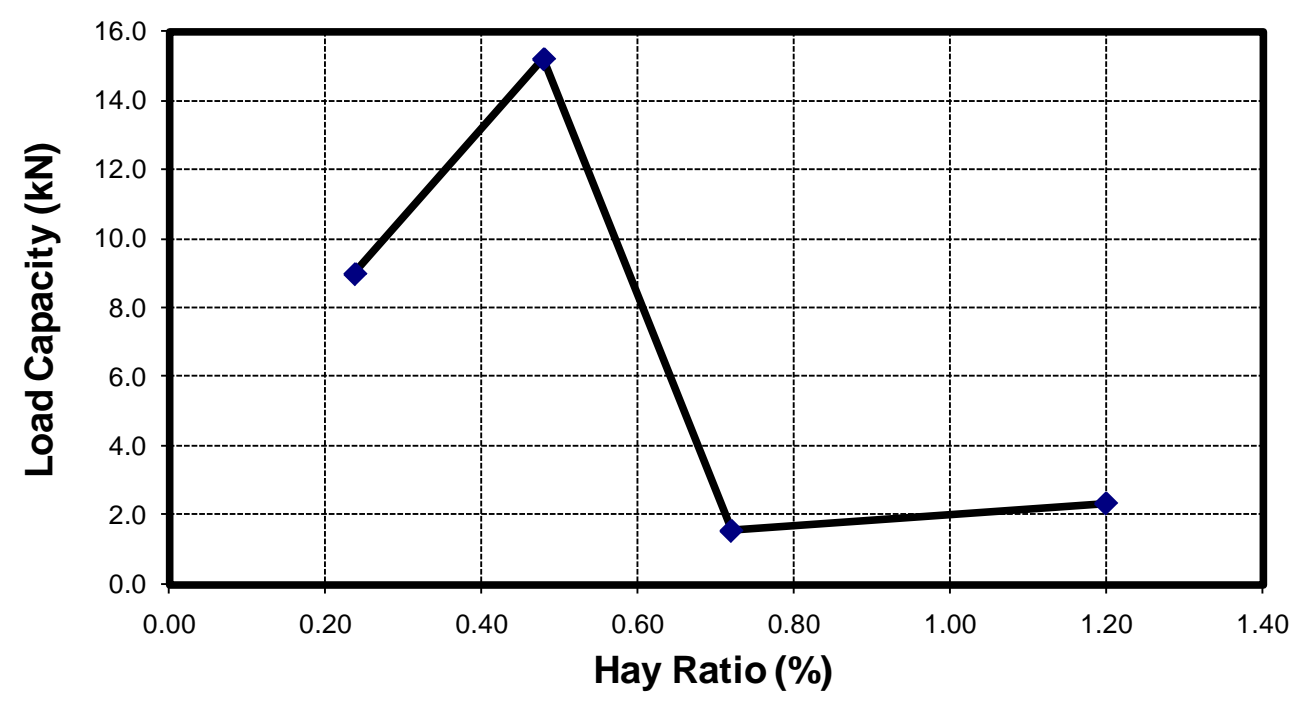

\section{Figure 8. Effect of hay ratio ratio on compressive strength.}

in Table 7 show that the addition of bitumen to the mixture with lime and hay had a negative effect on the compressive strength of the brick.

The ingredients of the samples of Group 8 are shown in Table 8 . The samples of this group have no sand. Lime was added with different ratios to mud, water, and hay. The test results of this group are shown in Figure 12. The results show that increasing the lime ratio leads to an increase in the compressive strength. In Figure 13, a comparison is made between the results of Group 6 containing sand and group 8 with no sand. This figure shows that exchanging the sand with lime had a positive effect on the load capacity of the bricks.

The effect of using different bonding materials in the basic sample consisting of sand, mud, and water is shown in Figure 14. Three types of bonding materials, namely, (hay), (steel fibers with no hay), (lime, hay, and steel filings), were used in the comparison shown in Figure 14. The results show that hay acts well when added to mud and sand to produce bricks.

Table 11 shows an overall analysis for the ten groups of samples considered in this study. The average load of each group was compared to control Group 2 where the samples consisted of a sand/mud ratio of 0.15 with a variable hay ratio. The results show that the major change in compressive strength was achieved in Group 3, where hay was replaced by cement as a binding material. 


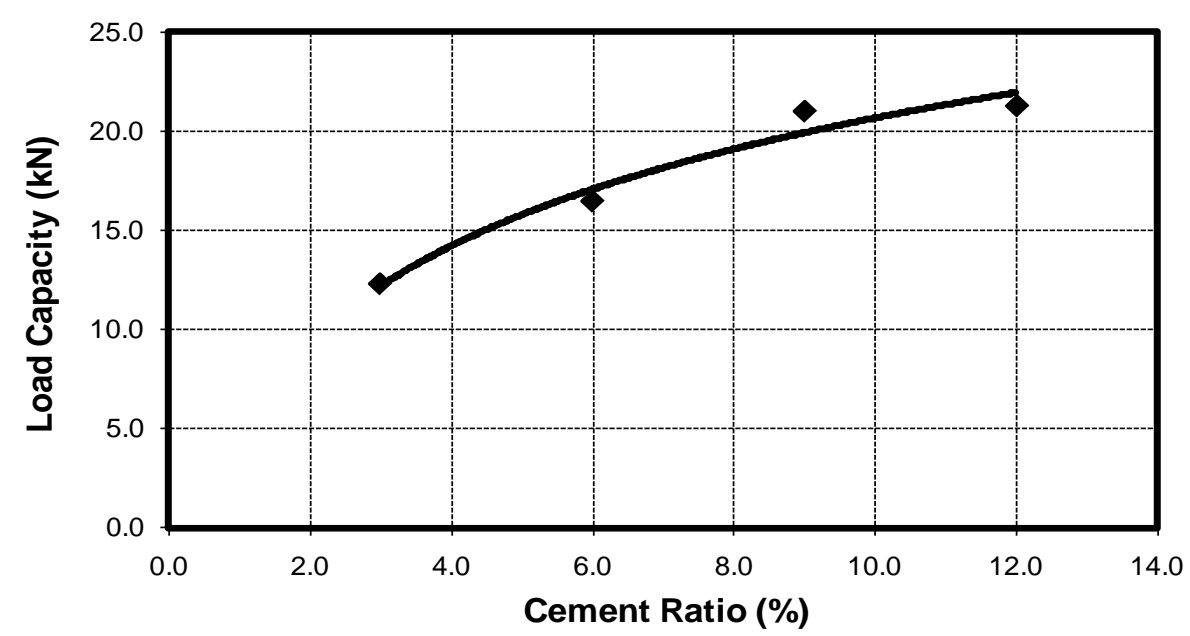

(a)

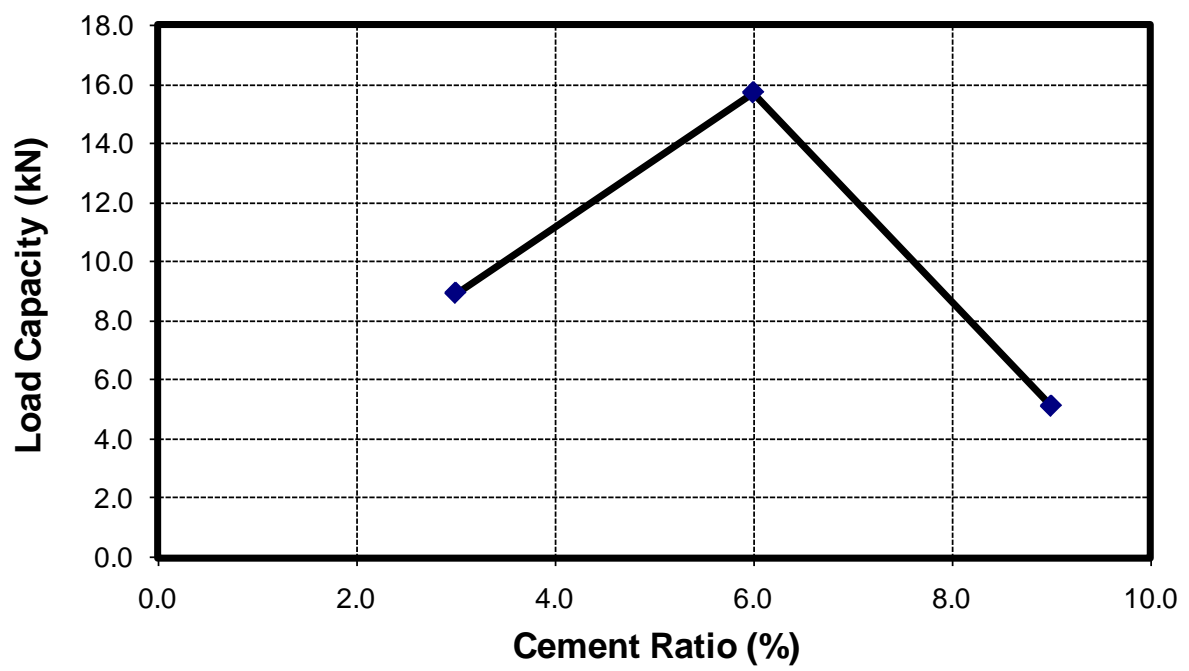

(b)

Figure 9. Effect of cement ratio on compressive strength: (a) without hay, and (b) with hay.

Table 11. Compressive strength analysis.

\begin{tabular}{cccc}
\hline Group No. & Variables Considered & Average Load $(\mathrm{KN})$ & \% Change compared to Group 2 \\
\hline 1 & Sand/Mud ratio & 5.90 & $36 \%$ \\
2 & Hay Ratio & 4.33 & $310 \%$ \\
3 & Cement Ratio & 17.78 & $129 \%$ \\
4 & Cement Ratio with Hay & 9.90 & $19 \%$ \\
5 & Lime Ratio & 5.15 & $13 \%$ \\
7 & Lime Ratio with Hay & 4.88 & $-52 \%$ \\
9 & Lime Ratio with Bitumen & 2.05 & $85 \%$ \\
10 & Lime Ratio with no Sand & 8.00 & $110 \%$ \\
\hline
\end{tabular}




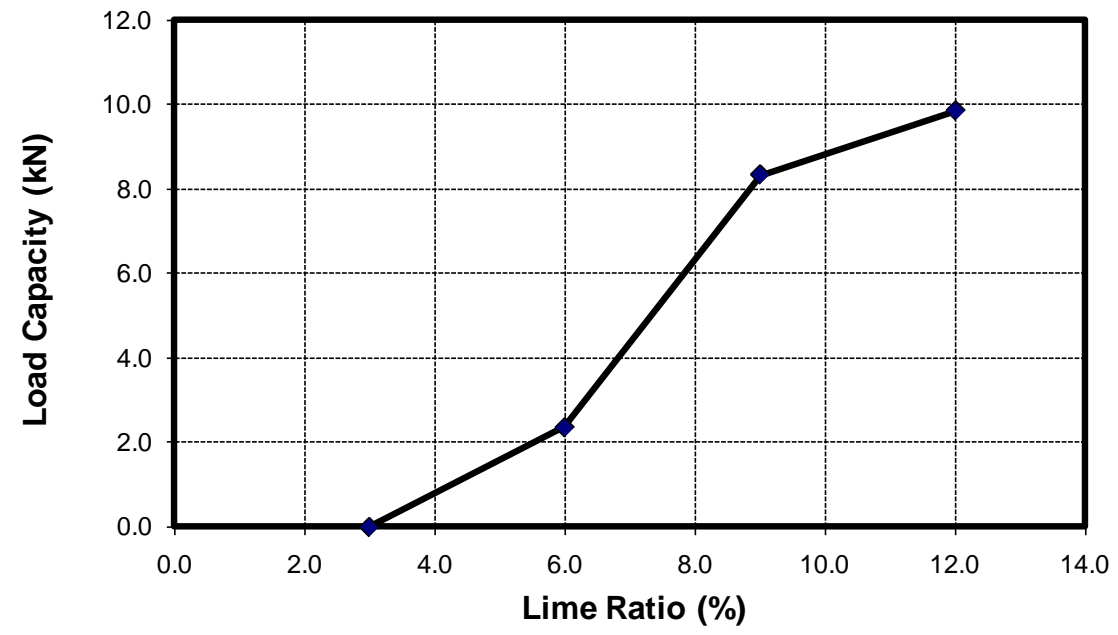

(a)

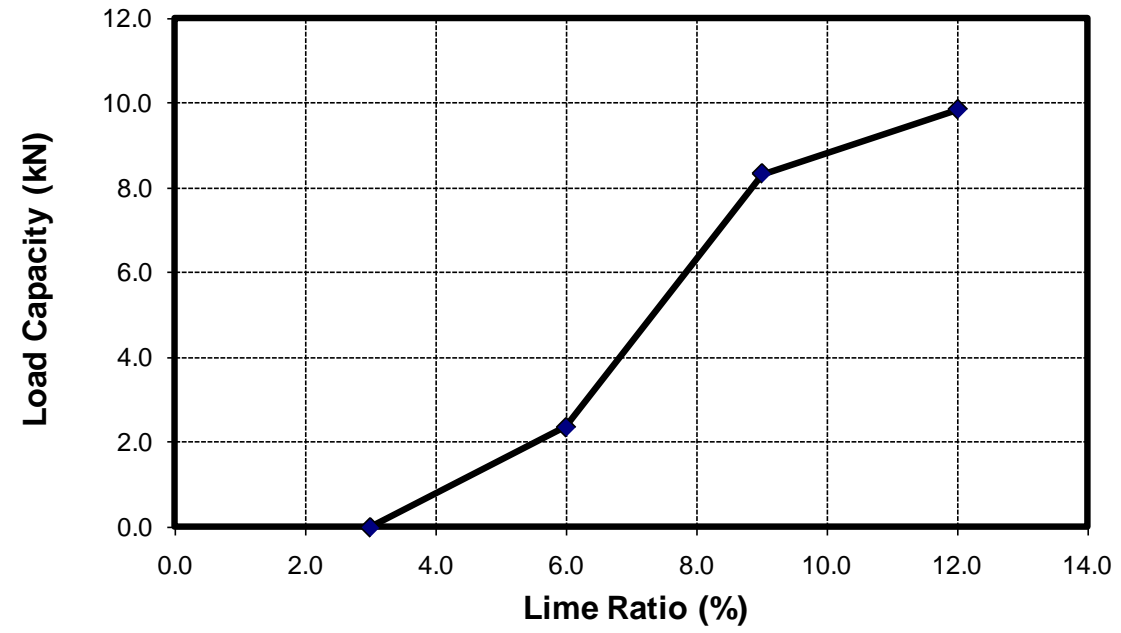

(b)

Figure 10. Effect of lime ratio on compressive strength: (a) without hay, and (b) with hay.

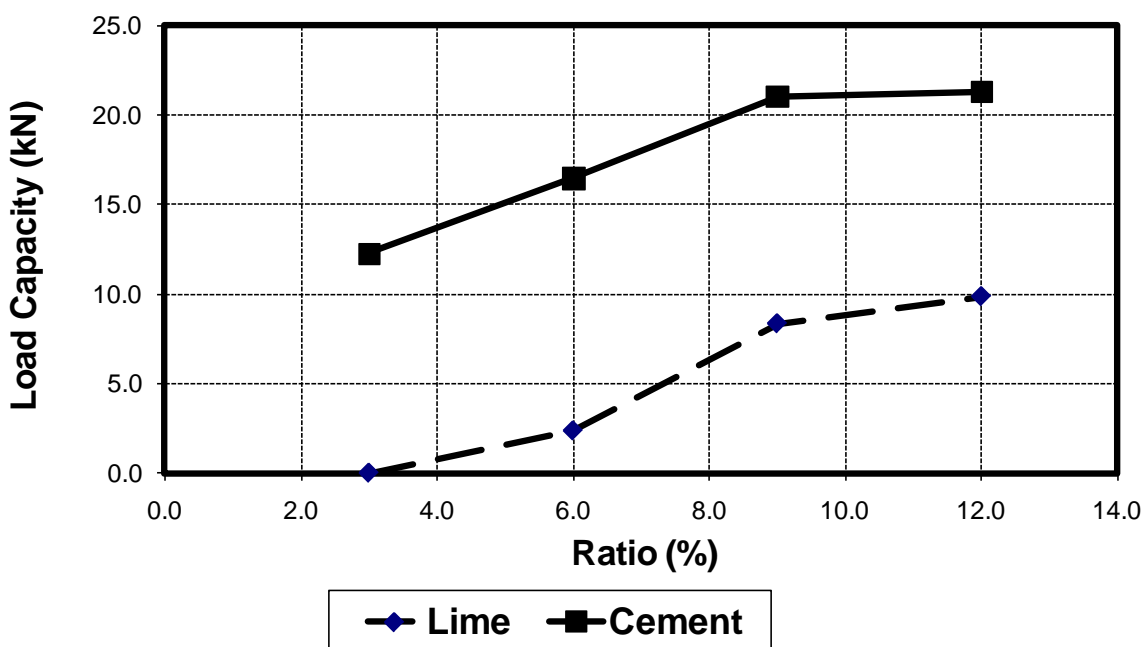

Figure 11. Effect of lime and cement ratios on compressive strength-no hay. 


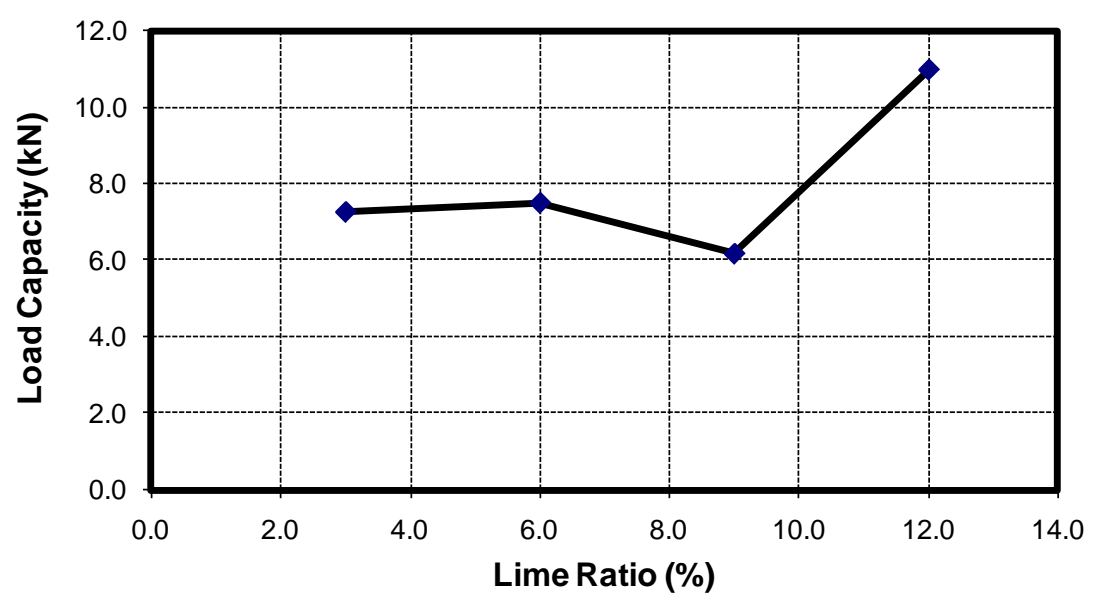

Figure 12. Effect of lime ratio on compressive strength—no sand.

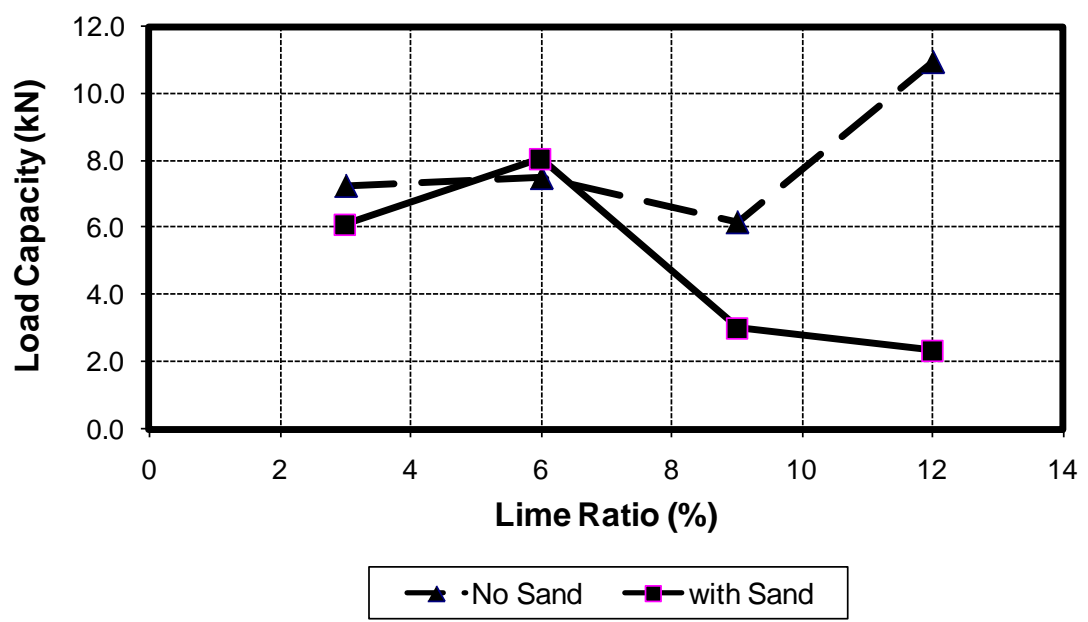

Figure 13. Effect of lime ratio on compressive strength.

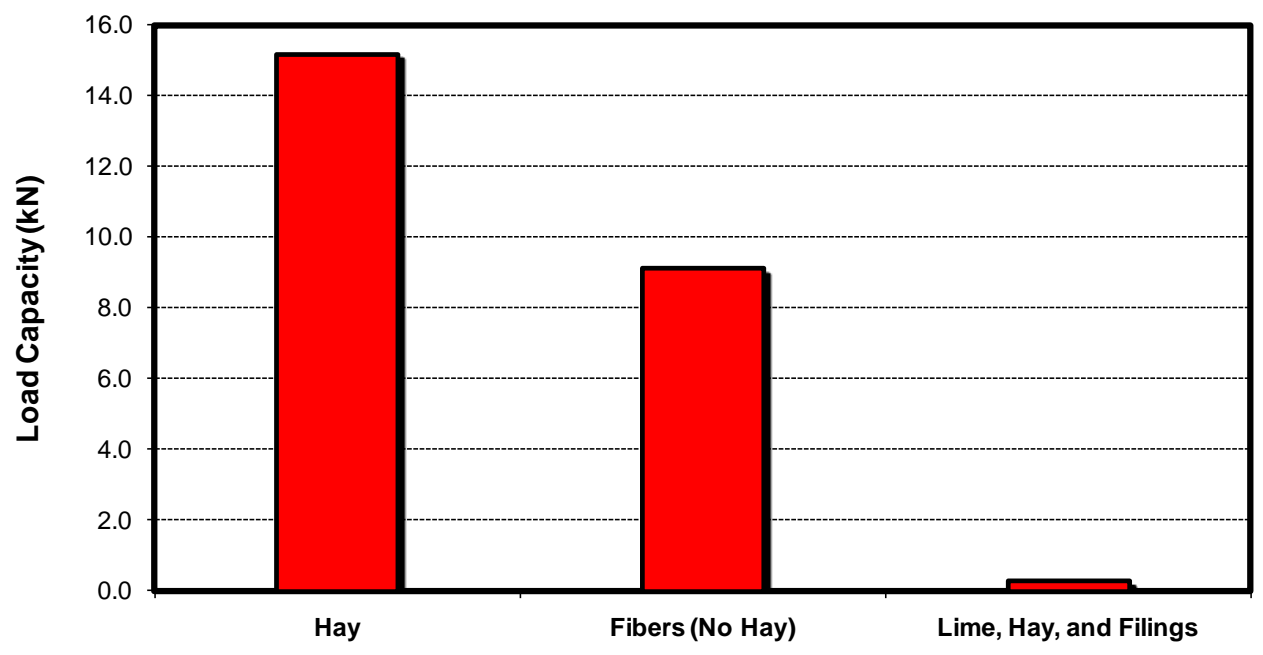

\section{Bonding Material}

Figure 14. Effect of bonding material on compressive strength. 


\section{Summary and Conclusions}

The compressive strength of mud brick was examined in this study. More than ninety tests were conducted to derive the optimum load capacity of the produced brick. The basic contents of the brick samples were mud, sand, and water. Different bonding materials were added to the basic brick mixture to reach the highest compressive capacity without sacrificing the initiative thermal property. The bonding materials considered in this study were: hay, cement, lime, bitumen, steel fibers, and steel filings. The results from the experimental investigation gave the following conclusions:

1) The optimum sand to mud ratio was 0.15 by weight. Increasing this ratio above 0.15 led to a decrease in the compressive strength of the brick samples.

2) Adding hay to the basic sample of mud, sand, and water had a great effect on the compressive strength of the produced brick. The optimum ratio of hay was $0.48 \%$ of the total weight of the sand and mud. Adding cement to the basic contents of the brick sample led to an increase in the compressive capacity of the produced brick. However, increasing the cement ratio might not be preferable due to its negative impact on thermal performance.

3) In case of basic specimens with hay, adding an extra bonding material such as lime or cement slightly increased the load capacity up to a certain limit, then compressive strength decreases.

4) Using steel fibers or steel filings as bonding materials did provide a notable increase in the load capacity of the mud brick.

5) The results showed that the major change in compressive strength was achieved in Group 3, where hay was replaced by cement as a binding material.

\section{References}

[1] Cofirman, R., Agnew, N., Auiston, G. and Doehne, E. (1990) Adobe Mineralogy Characterisation of Adobes from Around the World. In: Cruces, L., Ed., 6th International Conference on the Conservation of Earthen Architecture, Las Cruces, 14-19 October 1990, 424-429.

[2] Al-ajmi, F., Hanby, V. and Loveday, D. (2002) Thermal Performance of the Sub-Soil Environment in Dry Desert Climate. ASHRAE Transactions, 108, 395-405.

[3] Acostaa, I., Aineto, M., Romerob, M. and Rincon, J.M. (2002) Utilisation of IGCC Slag and Clay Steriles in Soft Mud Bricks (by Pressing) for Use in Building Bricks Manufacturing. Waste Management, 22, 887-891. http://dx.doi.org/10.1016/S0956-053X(02)00075-2

[4] Ren, K.B.D. and Kagi, A. (1995) Upgrading the Durability of Mud Bricks by Impregnation. Building and Environment, 30, 433-440.

[5] Al-awadhi, S. and Sayigh, A. (1990) The History Buildings Materials in Kuwait and Its Suitability to Local Climate. In: Sayigh, A.A.M., Ed., Energy and Environment into the 1990s, World Renewable Energy Company Limited, 4.

[6] Kuwait Institute for Scientific Research (KISR) Lab. (2006) Test for Thermal Conductivity Measurements. Report Submitted to Dr. Farraj Al-ajmi.

[7] Abu-Hamdeh, N.H., Khdair, A.I. and Reeder, R.C. (2001) A Comparison of Two Methods Used to Evaluate Thermal Conductivity for Some Soils. International Journal of Heat and Mass Transfer, 44, 1073-1078. http://dx.doi.org/10.1016/S0017-9310(00)00144-7 